\title{
BRINGING OUTSIDERS IN
}




\title{
BRINGING
}

\section{OUTSIDERS IN}

TRANSATLANTIC PERSPECTIVES

ON IMMIGRANT POLITICAL

INCORPORATION

Edited by

\author{
Jennifer L. Hochschild \\ and John H. Mollenkopf
}

Cornell University Press Ithaca and London 
Copyright $\odot 2009$ by Cornell University

Chapter 11 copyright $\odot 2009$ by Peter H. Schuck

An earlier version of Chapter 3 appeared in Rainer Bauböck (Ed.), Migration and Citizenship: Legal Status, Rights and Political Participation. IMISCOE Reports, Amsterdam University Press, 2006.

All rights reserved. Except for brief quotations in a review, this book, or parts thereof, must not be reproduced in any form without permission in writing from the publisher. For information, address Cornell University Press, Sage House, 512 East State Street, Ithaca, New York 14850 .

First published 2009 by Cornell University Press

First printing, Cornell Paperbacks, 2009

Printed in the United States of America

Library of Congress Cataloging-in-Publication Data

Bringing outsiders in : transatlantic perspectives on immigrant political incorporation / edited by Jennifer L. Hochschild and John H. Mollenkopf.

p. cm.

Papers originally presented at a conference held Apr. 22-23, 2005 at the Radcliffe Institute for Advanced Study.

Includes bibliographical references and index.

ISBN 978-0-8014-4811-9 (cloth : alk. paper) -

ISBN 978-0-8014-7514-6 (pbk. : alk. paper)

1. North America-Emigration and immigration-Political aspects-Congresses. 2. Europe, Western-Emigration and immigration-Political aspects-Congresses. 3. Immigrants-North America-Political activity-Congresses. 4. Immigrants--Europe, Western-Political activity-Congresses. 5. Political participationNorth America-Congresses. 6. Political participation-Europe, Western-Congresses. I. Hochschild, Jennifer L., 1950II. Mollenkopf, John H., 1946- III. Title.

JV6351.B75 2009

$325.73-\mathrm{dc} 22$

2008053441

Cornell University Press strives to use environmentally responsible suppliers and materials to the fullest extent possible in the publishing of its books. Such materials include vegetable-based, low-VOC inks and acid-free papers that are recycled, totally chlorine-free, or partly composed of nonwood fibers. For further information, visit our website at www.cornellpress.cornell.edu.

Cloth printing

10987654321

Paperback printing

10987654321 